Hydrol. Earth Sys. Sci. Discuss., 2, 1067-1085, 2005

www.copernicus.org/EGU/hess/hessd/2/1067/

Flux measurements

in the near surface

layer

Z. Gao et al.

\title{
Flux measurements in the near surface layer over a non-uniform crop surface in China
}

\section{Z. $\mathrm{Gao}^{1,2,3}$, L. Bian ${ }^{1}$, and S. Liu ${ }^{2}$}

${ }^{1}$ Chinese Academy of Meteorological Science, Beijing, China

${ }^{2}$ State Key Laboratory of Remote Sensing Science, School of Geography, Beijing Normal University, Beijing, China

${ }^{3}$ Jiangsu Province Key Laboratory of Meteorological Disaster and Environmental Variation, Nanjing, China

Received: 2 May 2005 - Accepted: 26 May 2005 - Published: 14 June 2005

Correspondence to: Z. Gao (zgao@ cams.cma.gov.cn)

(C) 2005 Author(s). This work is licensed under a Creative Commons License.

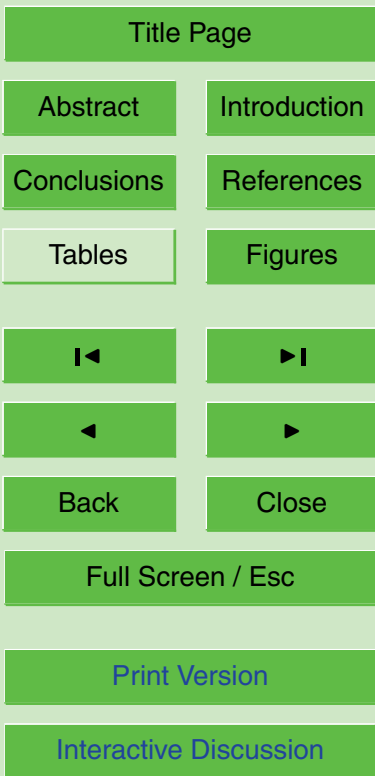




\section{Abstract}

Eddy covariance measurements were conducted on fluxes of moisture, heat and $\mathrm{CO}_{2}$ in a near-surface layer over a non-uniform crop surface in an agricultural ecosystem in the central plain of China from 10 June to 20 July 2002. During this period, the mean 5 canopy height was about $0.50 \mathrm{~m}$. The study site consisted of grass (10\% of area), bean $(15 \%)$, corn (15\%) and rice (60\%). Based on footprint analysis, we expected $>90 \%$ of the measured flux (at a height of $4 \mathrm{~m}$ above ground surface) to occur within the nearest $600 \mathrm{~m}$ of upwind area. We examined interdiurnal variations in the components of the surface energy balance and in $\mathrm{CO}_{2}$ flux. Results show that the pattern of energy partihad no obvious variation during the season. Daytime absorption of $\mathrm{CO}_{2}$ flux by the crop canopy suddenly increased after thunderstorm events. We examined the energy budget closure and found it to be around 0.85 . We compared energy partitioning for all rain-free days, and found energy imbalance was more significant for the 1 3 days after rainy events and energy components almost achieve balance for the other rain-free days. It indicated that the cold or warm rainwater infiltrating into soil made problems.

\section{Introduction}

The direct and indirect effects of increasing atmospheric $\mathrm{CO}_{2}$ may have profound implications for the structure and function of plant communities. Vegetation, in turn, plays a crucial role in the global carbon balance (Woodward et al., 1998; Mielnick et al., 2001). Climate simulations are especially sensitive to the surface partitioning of available energy into sensible and latent heat fluxes (e.g. Dickinson et al., 1991). Land surface processes are also critical in mesoscale atmospheric modeling (Chen and Dudhia, 2001; Sridhar et al., 2002). Agricultural ecosystem is one of the most widespread vegetation types in the world and therefore is a significant component of the earth's climate components and $\mathrm{CO}_{2}$ flux over homogenous crop surfaces (e.g. Harazono et al., 1998;

HESSD

2, 1067-1085, 2005

Flux measurements

in the near surface layer

Z. Gao et al.

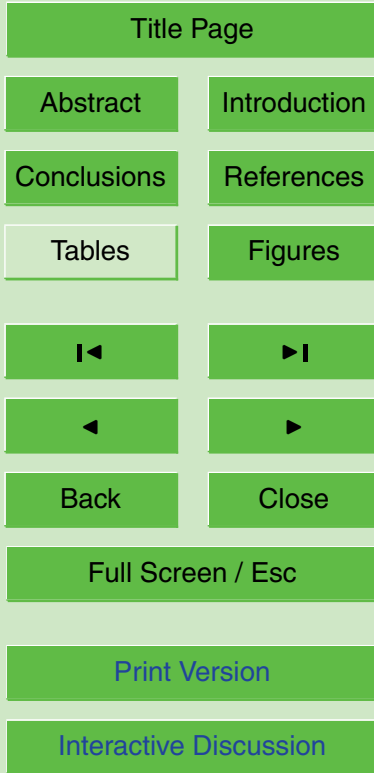

EGU 
Miyata et al., 2000; Gao et al., 2003). However, in Asia, if an agricultural region is larger than $5 \mathrm{~km} \times 5 \mathrm{~km}$, it must be non-uniform. It is especially true in China where farmers individually determine which type of crop for their rented fields. On the other hand, because climate and mesoscale modelers need to better parameterize near surface

5 fluxes in their models, and researchers who devote interests to surface flux estimate from satellite strongly need to improve current retrieval algorithms, they all need accurate fluxes measured at the surfaces which represent large landscapes well. Field studies designed to characterize land surface processes in agricultural ecosystem are thus needed. To improve the current understanding of energy partitioning and $\mathrm{CO}_{2}$ 10 exchange in the main agricultural ecosystem in China, we conducted an intensive nonuniform surface experiment in China's Anhui province from 10 June to 20 July 2002. The site is typical of plains in central China. The objective of this note is therefore to present measurement results obtained in this micrometeorological field study.

\section{Materials and methods}

\section{2.1. Site}

The experiment was carried out at a conventional meteorological site $\left(31^{\circ} 41^{\prime} \mathrm{N}\right.$, $117^{\circ} 08^{\prime} \mathrm{E}$ ) in the main agricultural ecosystem of China during the period from 10 June to 20 July 2002 . Soil at the experimental site was predominantly clay loam. The site surface was non-uniform, and consisted of grass (10\%), bean (15\%), corn (15\%), and rice $(60 \%)$ around. The predominant wind direction was south-east during the period of the experiment. On 6 June 2002 the micrometeorological instrumentation was set up. During the experiment the rice canopy height increased from $0.16 \mathrm{~m}$ to $0.65 \mathrm{~m}$ and the rice field was flooded throughout the entire experiment. The grass canopy height was $0.1 \mathrm{~m}$; bean height increased from $0.3 \mathrm{~m}$ to $0.55 \mathrm{~m}$; and corn height increased from $0.3 \mathrm{~m}$ to $1.2 \mathrm{~m}$.

HESSD

2, 1067-1085, 2005

\section{Flux measurements in the near surface layer}

Z. Gao et al.

\section{Title Page}

Abstract

Conclusions

Tables

\section{4}

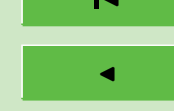

Back
Introduction

Figures

$\rightarrow 1$

Close
References

Full Screen / Esc

Print Version

Interactive Discussion

EGU 
A three-dimensional ultrasonic anemometer (CSAT3, Campbell Scientific Inc.) was used to measure the means and standard deviations of the wind velocity components (i.e. $u, v$ and $w$ ); a Krypton hygrometer ( $\mathrm{KH} 20$, Campbell Scientific Inc.) was used

5 to measure the mean and standard deviation of water vapor density; and a fine-wire thermocouple (FW05) was used to measure the mean and standard deviation of air temperature. These sensors were installed at $4.0 \mathrm{~m}$ above the ground surface. All signals for the sensors were recorded at a sampling rate of $20 \mathrm{~Hz}$ and were averaged over 30 min periods.

Webb et al. (1980) showed that the eddy flux of heat should be calculated using the heat capacity of moist air and the covariance between temperature and vertical wind speed, and that corrections are needed for density fluctuations in calculating the fluxes of water vapor and $\mathrm{CO}_{2}$. So we corrected the latent heat flux for the variation in air density owing to the transfer of sensible heat, and corrected the sensible heat flux for the variation in air density owing to the latent heat flux. Webb et al. (1980) corrections were also used for $\mathrm{CO}_{2}$ flux. Following Moore (1986), we corrected eddy covariance values for the effects of path length averaging of the sonic anemometer and the gas analyzer, and for spatial separation of sensors.

The ultrasonic anemometer was tested for accuracy in the wind tunnel at the Meter20 ing Station of the China Meteorological Administration and found that they gave consistent results. The measured composite horizontal winds differed systematically by only $\sim 1 \%$ from the actual wind, although the differences were larger at speeds $<0.5 \mathrm{~ms}^{-1}$. During the fieldwork we compared the output voltage $V$ from the infrared hygrometer (E009B) to the specific humidity $q$ in various bands of specific humidity and found that $25 \quad V$ was a linear function of $q$.

We eliminated noise and various kinds of interference from the 30-min measurements of turbulence by using a criterion of $X(t)<(\bar{X}-4 \sigma)$ or $X(t)>(\bar{X}+4 \sigma)$, where $X(t)$ denotes the measurement (i.e. wind speed, temperature), $\bar{X}$ the mean over the interval,

\section{Flux measurements in the near surface layer}

Z. Gao et al.

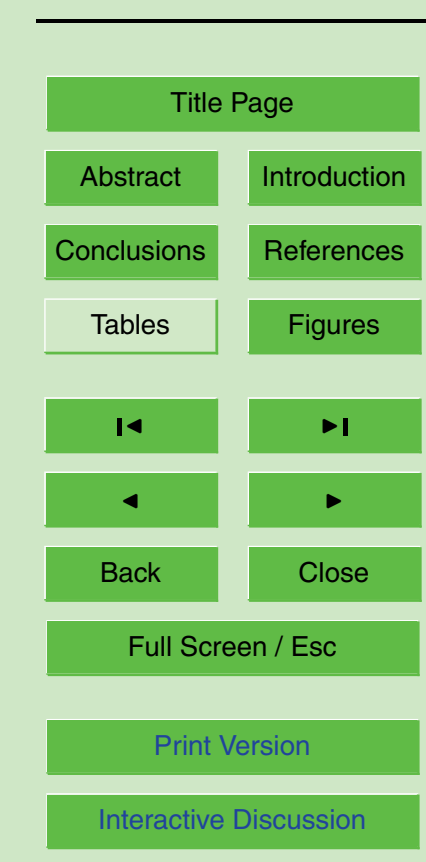

EGU 
and $\sigma$ the standard deviation. We interpolated by averaging the sample immediately before the sample to be removed with the one immediately after it. Data during precipitation events was removed because the sonic anemometer and Krypton hygrometer would not give accurate results under such conditions.

5 The set of observational data includes these meteorological quantities: horizontal wind speed, air temperature, specific humidity, $\mathrm{CO}_{2}$ density and precipitation. These data were collected at the height of $4.0 \mathrm{~m}$ above water. As shown in Fig. 1, air temperature and $\mathrm{CO}_{2}$ density undergo a marked diurnal cycle, but they have contrary phases. It must be noted that in the period selected there are a lot of gaps that were caused by 10 rainy events. Two thunderstorm events happened during our experiential period. One is for the period from 02:00 to 10:00 (LT) on DOY 175 (i.e. 24 June), and the maximum precipitation intensity reached $25.5 \mathrm{~mm} \mathrm{~h}^{-1}$; the other is for the period from 13:00 to 17:00 (LT) on DOY 178 (i.e. 27 June), and the maximum precipitation intensity reached $41.1 \mathrm{~mm} \mathrm{~h}^{-1}$.

15 Gao et al. (2003) investigated the aerodynamic roughness length $\left(z_{0}\right)$ and zero plane displacement $(d)$ of a rice paddy under different conditions. They found that $z_{0}$ and $d$ are $0.027 \mathrm{~m}$ and $0.43 \mathrm{~m}$ respectively, and $z_{0}$ increased with increasing wind speed when the height of the rice was $>0.5 \mathrm{~m}$. In this study, we assumed that $d \approx 3 \mathrm{~h} / 4$, where $h$ is the canopy height, which was determined by an area-weight average for upwind area (wind direction $\pm 30^{\circ}$ ). The average surface roughness length $z_{0}$ of approximately $0.024 \mathrm{~m}$ was derived from the ultrasonic anemometer data under near neutral conditions (Katul et al., 1995) for our experimental period.

\subsection{Flux computations}

Surface energy balance in an agricultural crop surface can be approximated as

$25 R n=H+L E+G_{0}$,

where $R n, H, L E$ and $G_{0}$ are the net radiation, sensible heat, latent heat and soil heat fluxes respectively. Eddy fluxes of sensible heat and latent heat were computed as

HESSD

2, 1067-1085, 2005

Flux measurements in the near surface layer

Z. Gao et al.

\section{Title Page}

Abstract Introduction

Conclusions References

Tables Figures

14

$\triangleleft$

Back

Close

Full Screen / Esc

Print Version

Interactive Discussion 
(e.g. Kaimal and Finnigan, 1994):

HESSD

$H=\bar{\rho} C_{p} \overline{w^{\prime} T^{\prime}}$,

2, 1067-1085, 2005

$L E=L \bar{\rho} \overline{W^{\prime} q^{\prime}}$,

where $\bar{\rho}, C_{p}$ and $L$ are the density of air $\left(\mathrm{kg} \mathrm{m}^{-3}\right)$, the specific heat of air $\left(\mathrm{J} \mathrm{kg}^{-1} \mathrm{~K}^{-1}\right)$, 5 and latent heat of vaporization $\left(\mathrm{J} \mathrm{kg}^{-1}\right)$, respectively. $w^{\prime}, T^{\prime}$ and $q^{\prime}$ are the fluctuations of vertical wind component $\left(\mathrm{m} \mathrm{s}^{-1}\right)$, air temperature $(K)$ and specific humidity, respectively.

With no other sources/sinks of heat in the soil at our site, the surface soil heat flux $\left(G_{0}\right)$ was calculated as:

${ }_{10} G_{0}=G_{1}+C_{s} \Delta z^{\prime} \partial T_{s} / \partial t$,

where $G_{1}$ is the soil heat flux measured at $0.05 \mathrm{~m}$ below the soil surface $\left(\mathrm{W} \mathrm{m}^{-2}\right) ; C_{s}$ is the volumetric heat capacity of soil $\left(2.42 \times 10^{6} \mathrm{~J} \mathrm{~m}^{-3} \mathrm{~K}^{-1}\right.$, Stull, 1988), $\Delta z^{\prime}=0.05 \mathrm{~m}$, and $T_{s}$ is the mean temperature of $0-0.05 \mathrm{~m}$ soil layer, calculated from the temperatures measured at surface and at $0.05 \mathrm{~m}$ depth.

Net radiation $(R n)$ can be obtained by

$R n=I S R+I L R-O S R-O L R$,

where ISR and ILR are downward short- and long-wave radiation, OSR and OLR are upwelling reflected short-wave radiation and long-wave radiation emitted by surface, respectively.

Since the 1980s, the development of fast response $\mathrm{CO}_{2}$ analyzers enabled us to directly measure $\mathrm{CO}_{2}$ fluxes over rice canopies using eddy covariance methods. Ohtaki and Matsui (1982) and Ohtaki (1984) defined the following equation to reliably estimate $\mathrm{CO}_{2}$ flux:

$F_{\mathrm{CO}_{2}}=\overline{W^{\prime} C^{\prime}}$,

Flux measurements

in the near surface layer

Z. Gao et al.

Title Page

Abstract

Introduction

Conclusions

References

Tables

Figures

14

$\triangleleft$

Back

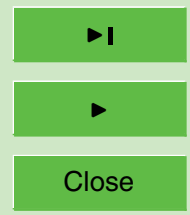

Full Screen / Esc

Print Version

Interactive Discussion

EGU 
where $\mathrm{F}_{\mathrm{CO}_{2}}$ is $\mathrm{CO}_{2}$ flux $\left(\mathrm{mg} \mathrm{m}^{-2} \mathrm{~s}^{-1}\right), c^{\prime}$ is the fluctuation in the concentration of $\mathrm{CO}_{2}$ $\left(\mathrm{mg} \mathrm{m} \mathrm{m}^{-3}\right.$ ).

HESSD

\subsection{Fetch analysis}

The adequacy of the fetch may be confirmed by footprint analysis (e.g. Schuepp et al., 5 1990; Harazono et al., 1998). The cumulative normalized contribution to the surface flux from upwind locations, $C_{F}\left(\chi_{L}\right)$, can be expressed as

$C_{F}\left(\chi_{L}\right)=e^{-U(z-d) /\left(k u_{*} \chi_{L}\right)}$,

where $d$ is the zero plane displacement, $k$ is von Karman's constant, $u_{*}$ is the friction velocity, $\chi_{L}$ is the distance upwind of the measuring point, and $U$ is the average wind

2, 1067-1085, 2005

Flux measurements

in the near surface

layer

Z. Gao et al.

\section{Title Page} 10 speed between the surface and observation height $z$. Assuming a logarithmic profile for horizontal wind speed $u(z)$, with $z, U$ is given by

$U=\int_{d+z_{0}}^{z} u(z) d z / \int_{d+z_{0}}^{z} d z=\frac{u_{*}\left[\ln \left((z-d) / z_{0}^{\prime}-1+z_{0} /(z-d)\right]\right.}{k\left(1-z_{0} /(z-d)\right)}$.

Abstract

Conclusions

Tables

14

\section{Results and discussion}

\subsection{Fetch analysis}

Data were collected at $4.0 \mathrm{~m}$ above the ground surface, which was well above the canopy ( $z>3 h$, where $h$ is the crop canopy height) and thus the flow assumes the inertial sub layer properties of the conventional atmospheric surface layer such as the constant flux region. To estimate the average footprint for whole observational period, where $d=0.37 \mathrm{~m}$ on average, the contributions of the cumulative flux were computed

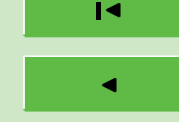

Back

\section{Full Screen / Esc}

Print Version

Interactive Discussion 
the measured flux at the measurement height was expected to come from within the nearest $600 \mathrm{~m}$ of upwind area for neutral stability during the entire period.

HESSD

3.2. Variations throughout the entire experiment

2, 1067-1085, 2005

\subsubsection{Radiation balance components}

5 The measured interdiurnal variations of surface radiation components at a height of 1.5 $\mathrm{m}$ at our site from 10 June to 20 July 2002 are shown in Fig. 3, where coinstantaneous precipitation (prec.) distribution is also given. It can be seen that all components of radiation fluxes varied diurnally, and downward shortwave radiation (DSR) flux was strong and the daily peak often exceeded $700 \mathrm{Wm}^{-2}$ around noon during clear days.

10 A large amount of solar energy can be received by the surface as the albedo $(0.17)$ is low. This value $(0.17)$ agrees with the representative value $(0.15-0.25)$ of short-wave albedo for crop surfaces (Garratt, 1992). We note that, owing to the cloud existence, downward shortwave radiation flux, upward shortwave radiation (USR) flux and upward long-wave radiation $(U L R)$ flux were significant low, and downward long-wave radiation $15(D L R)$ flux was high during rainy period. Net radiation can be derived by radiation budget as shown in Fig. 4. We can regard net radiation $(R n)$ as an external force, while the sensible flux $(H)$, latent flux $(L E)$, and ground flux $\left(G_{0}\right)$ are the responses.

\subsubsection{Energy balance components}

Figure 4 illustrates the time series of energy budget components obtained by direct measurements for the entire experimental period. Our analyses on the surface energy balance in this section are focused on the data collected on clear days (i.e. DOYs: $162-163,165,169,177,183,188-195$, and 200), because the sonic anemometer and Krypton hygrometer would be in error during and after rain events, and the cold or warm rainwater infiltrating into soil would create complexities. The diurnal patterns of $R n, H, L E$ and $G_{0}$ barely changed for these clear days, indicating that the energy

Flux measurements in the near surface layer

Z. Gao et al.

\section{Title Page}

Abstract Introduction

Conclusions

Tables

References

Figures

14

4

Back

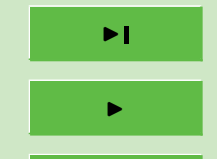

Close

Full Screen / Esc

Print Version

Interactive Discussion

EGU 
partition barely changed. The maximum value of $R n$ was $\sim 600 \mathrm{~W} \mathrm{~m}^{-2}$, the maximum value of $L E$ reached $229 \mathrm{~W} \mathrm{~m}^{-2}$, the maximum value of $H$ was $145 \mathrm{~W} \mathrm{~m}^{-2}$, and the maximum value of $G_{0}$ was $215 \mathrm{~W} \mathrm{~m}^{-2}$ on the basis of direct measurements. The Bowen ratio $\beta(\beta \equiv H / L E)$, on average, was 0.49 for our experimental period.

The interdiurnal course of $\mathrm{CO}_{2}$ fluxes above the canopy measured by the eddy covariance method is shown in Fig. 4, where a negative sign denotes downward and means the canopy absorbed $\mathrm{CO}_{2}$ from the atmosphere. In contrast to energy partition mentioned above, $\mathrm{CO}_{2}$ flux $\left(\mathrm{F}_{\mathrm{CO}_{2}}\right)$ absorbed by the canopy suddenly increased 10 after thunderstorm events, as shown in Fig. 4. This was likely caused by quick growth of crop canopy which changed both leaf area index ( $\mathrm{LAI}$ ) and photosynthetically active radiation. The maximum value of $\mathrm{CO}_{2}$ flux absorbed by crop canopy was $0.81 \times 10^{-6} \mathrm{~kg}$ $\mathrm{m}^{-2} \mathrm{~s}^{-1}$ during our experimental period. It is about half of that obtained over a pure rice paddy (Gao et al., 2003). This difference is likely caused by the different both leaf area index (LAI) and photosynthetically active radiation for two different surfaces.

\subsubsection{Soil temperature and soil volume water content}

Figure 5a shows the time series of soil temperatures at ground surface and at three depths in the soil covered by short grass. It is apparent that soil temperature, in shallow surface layer, responded to solar radiation, precipitation and soil volume water content sensitively. Figure $5 \mathrm{~b}$ shows the time series of the soil volume water content obtained by direct measurements in $0-0.15 \mathrm{~m}$ surface layer and $0.15-0.30 \mathrm{~m}$ soil layer in the soil covered by grass at our site. Figure $5 \mathrm{c}$ shows the time series of the precipitation. We find that (a) in both two soil layers, soil volume water content responded to precipitation sensitively with the most striking cases happened on DOYs 161, 170, 171, 174, 178, and 179, when a thunderstorm made the greatest sudden change of soil wetness; and (b) soil volume water content gradually decreased owing to evaporation from bare soil

\section{Flux measurements in the near surface layer}

Z. Gao et al.

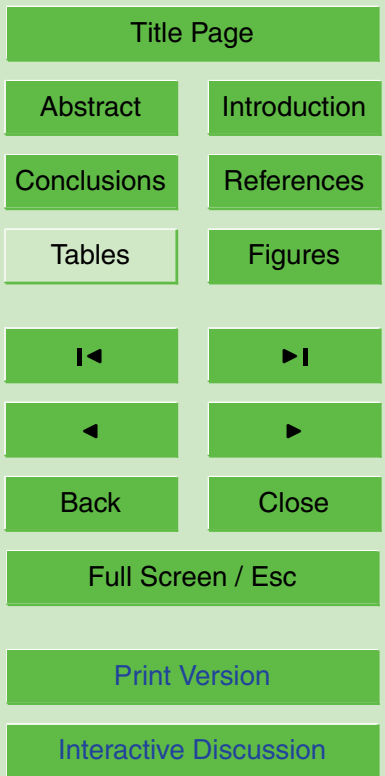


Surface energy budget closure, $\varepsilon$, defined as the ratio of the sum of sensible and latent heat fluxes $(H+L E)$ to available energy (the difference of net radiation and soil heat flux:

$5 R n-G_{0}$ ) (Gu et al., 1999), has been prescribed to examine the surface energy balance. Ideally, $\varepsilon$ should be equal to one, when the surface energy balance (i.e. partitioning of $R n$ into $H, L E$, and $G_{0}$ ) is perfectly closed. Figure 6 gives the inter-comparison of $H+L E$ and available energy $\left(R n-G_{0}\right)$. It is found that the mean value of energy budget closure $(\varepsilon)$ is about 0.85 . To clarify on which days energy imbalance were - more significant for all rain-free days, we plot the bar graph of all daily averaged energy components and residual energy $\left(R e \equiv R n-H-L E-G_{0}\right)$ in Fig. 7. It is obvious that the energy imbalance was significant during the 1 3 days after rain events (i.e. DOYs 162$163,176-177,182-183,189-191$, and 200), and energy components almost achieved balance for other rain-free days.

\section{Summary and conclusions}

In this paper we have reported our measurements of the energy budget components and $\mathrm{CO}_{2}$ exchange over a non-uniform crop surface in an agricultural ecosystem in China from 10 June to 20 July 2002.

Daily patterns of latent heat $(L E)$, sensible heat flux $(H)$, surface heat flux $\left(G_{0}\right)$ and $\mathrm{CO}_{2}$ flux (contrary phase) followed that of net radiation $(R n)$.

The energy closure ratio $(\varepsilon)$ averaged 0.85 during the experiment, and energy imbalance mainly happened during the 1 3 days after rain events. So we concluded that the cold or warm rainwater infiltrating into soil made problems. Meanwhile, energy components almost achieved balance for other rain-free days. Hence, our flux data are of sufficiently good quality not only for quantification but also for other applications

\section{Flux measurements in the near surface layer \\ Z. Gao et al.}

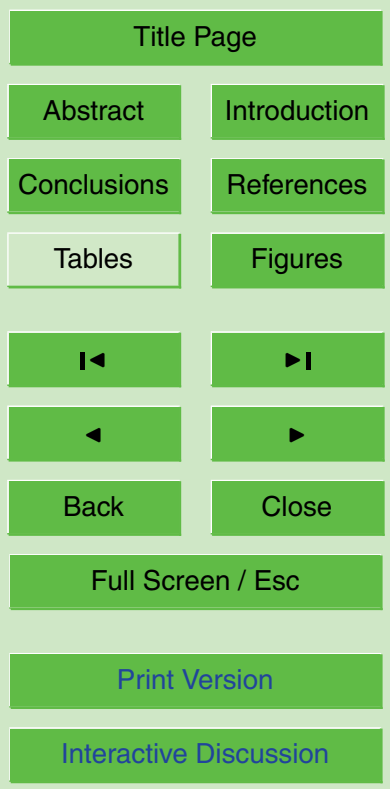

EGU 
such as model validation and calibration.

Main new finding of this research is that, with the crop growth, the pattern of energy partition and the magnitude of energy budget components remained fairly constant. The energy closure ratio $(\varepsilon)$ had no obvious variation during the experiment. In con5 trast, crop canopy absorbed more $\mathrm{CO}_{2}$ during the daytime with the crop growth. The maximum value of $\mathrm{CO}_{2}$ flux absorbed by canopy was $0.81 \times 10^{-6} \mathrm{~kg} \mathrm{~m}^{-2} \mathrm{~s}^{-1}$ during our experimental period.

Acknowledgements. This study was financially supported by the National Key Basic Research and Development Project of China through Research on Theories and Methods of Monitoring 10 and Predicting of Heavy Rainfall in South China (2004CB418300). Special thanks to L. Lu, $\mathrm{X}$. Wang and $\mathrm{C}$. Lu for their support in field data collection.

\section{References}

Chen F., and J. Dudhia, Coupling an advanced land-surface/hydrology model with the Penn State-NCAR MM5 modeling system, part I, Model implementation and sensitivity, Mon. Weather Rev., 129, 569-582, 2001.

Dickinson, R. E., Hendersin-Sellers, A., Rosenzweig, C., and Sellers, P. J.: "Evapotranspiration models with canopy resistance for use in climate models, a review", Agric. For. Meteorol., 54, 373-388, 1991.

Garratt, J. R.: The Atmospheric Boundary Layer, Cambridge University Press, New York, USA, 291-292, 1992.

Gao, Z., Bian, L., and Zhou, X.: Measurements of Turbulent Transfer in the Near-surface Layer over a Rice Paddy in China, J. Geophys. Res., 108, D13, 4387, dio:10.1029/2002JD002779, 2003.

Harazono, Y., Kim, J., Miyata, A., Choi, T., Yun, J.-I., and Kim, J.-W.: Measurement of energy 25 budget components during the International Rice Experiment (IREX) in Japan, Hydrological Processes, 12, 2018-2092, 1998.

Kaimal. J. C. and Finnigan, J. J.: Atmospheric boundary layer and flows, Oxford University Press, 289, 1994.
HESSD

2, 1067-1085, 2005

\section{Flux measurements \\ in the near surface layer}

Z. Gao et al.

\section{Title Page}

\section{Abstract}

Introduction

Conclusions

References

Tables

Figures

14

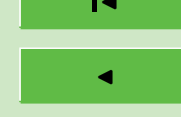

$\rightarrow 1$

Back

Close

Full Screen / Esc

Print Version

Interactive Discussion 
Katul, G. G., Goltz, S. M., Hsieh, C.-I., Cheng, Y., Mowry, F., and Sigmon, J.: Estimation of surface heat and momentum fluxes using the flux-variance method above uniform and nonuniform terrain, Bound.-Layer Meteorol., 74, 237-260, 1995.

Mielnick, P. C., Dugas, W. A., Johnson, H. B., Polley, H. W., and Sanabria, J.: Net grassland 5 carbon flux over a subambient to superambient $\mathrm{CO}_{2}$ gradient, Global Change Biology, 7, 747-754, 2001.

Miyata, A., Leuning, R., Denmead, O. T., Kim, J., and Harazono, Y.: Carbon dioxide and methane fluxes from an intermittently flooded paddy field, Agricultural and Forest Meteorology, 102, 287-303, 2000.

10 Moore, C. J.: Frequency response to corrections for eddy correlation system, Bound.-Layer Meteor., 37, 17-35, 1986.

Ohtaki, E.: Application of an inferred carbon dioxide and humidity instrument to studies of turbulent transport, Bound.-Layer Meteor., 29, 85-107, 1984.

Ohtaki, E. and Matsui, T.: Infrared device for simultaneous measurement of atmospheric carbon dioxide and water vapor, Bound.-Layer Meteor., 24, 109-119, 1982.

Schuepp, P. H., Leclerc, M. Y., MacPherson, J. I., and Desjardins, R. L.: Footprint prediction of scalar fluxes from analytical solution of the diffusion equation, Bound.-Layer Meteor., 50, 355-373, 1990.

Sridhar, V., Elliott, R. L., Chen, F., and Brotzge, J. A.: Validation of the NOAH-OSU land surface model using surface flux measurements in Oklahoma, J. Geophys. Res., 107, D20, 4418, dio:10.1029/2001JD001306, 2002.

Stull, R. B.: An Introduction to Boundary Layer Meteorology, Kluwer Acad., Norwell Mass., 274-287, 1988.

Webb, E. K., Perman, G. I., and Leuning, R.: Correction of flux measurements for density effects due to heat and water transfer, Quart, J. Roy. Meteor. Soc., 106, 85-100, 1980.

Woodward, F. L., Lomas, M. R., and Betts, R. A.: Vegetation-climate feedbacks in a greenhouse world, Philosophical Transactions of the Royal Society, London, 353, 29-39, 1998.

Flux measurements

in the near surface layer

Z. Gao et al.

\section{Title Page}

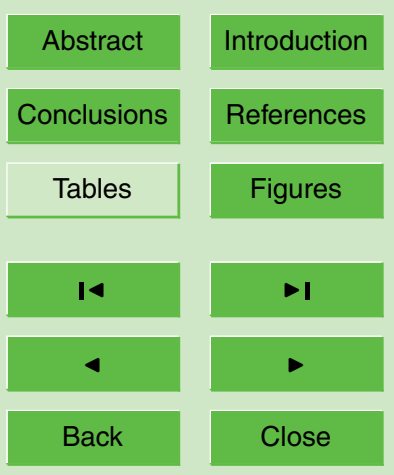

Full Screen / Esc

Print Version

Interactive Discussion

EGU 


\section{HESSD}

2, 1067-1085, 2005
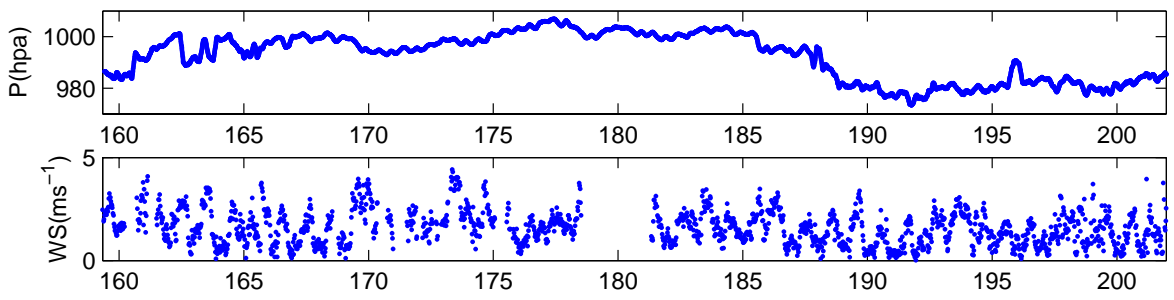

\section{Flux measurements in the near surface layer \\ Z. Gao et al.}

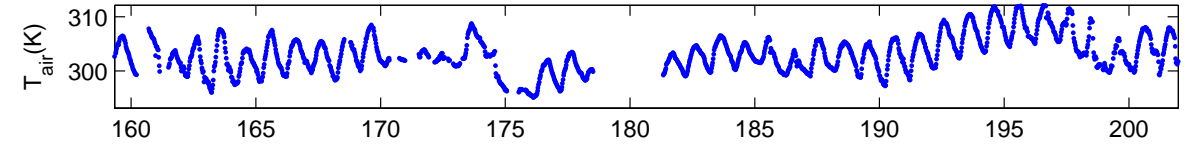

\section{Title Page}

\begin{tabular}{|c|c|}
\hline Abstract & Introduction \\
\hline Conclusions & References \\
\hline Tables & Figures \\
\hline 14 & $\rightarrow 1$ \\
\hline 4 & $\triangleright$ \\
\hline Back & Close \\
\hline
\end{tabular}

\section{Full Screen / Esc}

Print Version

Fig. 1. Hourly meteorological data for 10 June to 20 July 2002 over a non-uniform crop surface. 


\section{HESSD}

2, 1067-1085, 2005

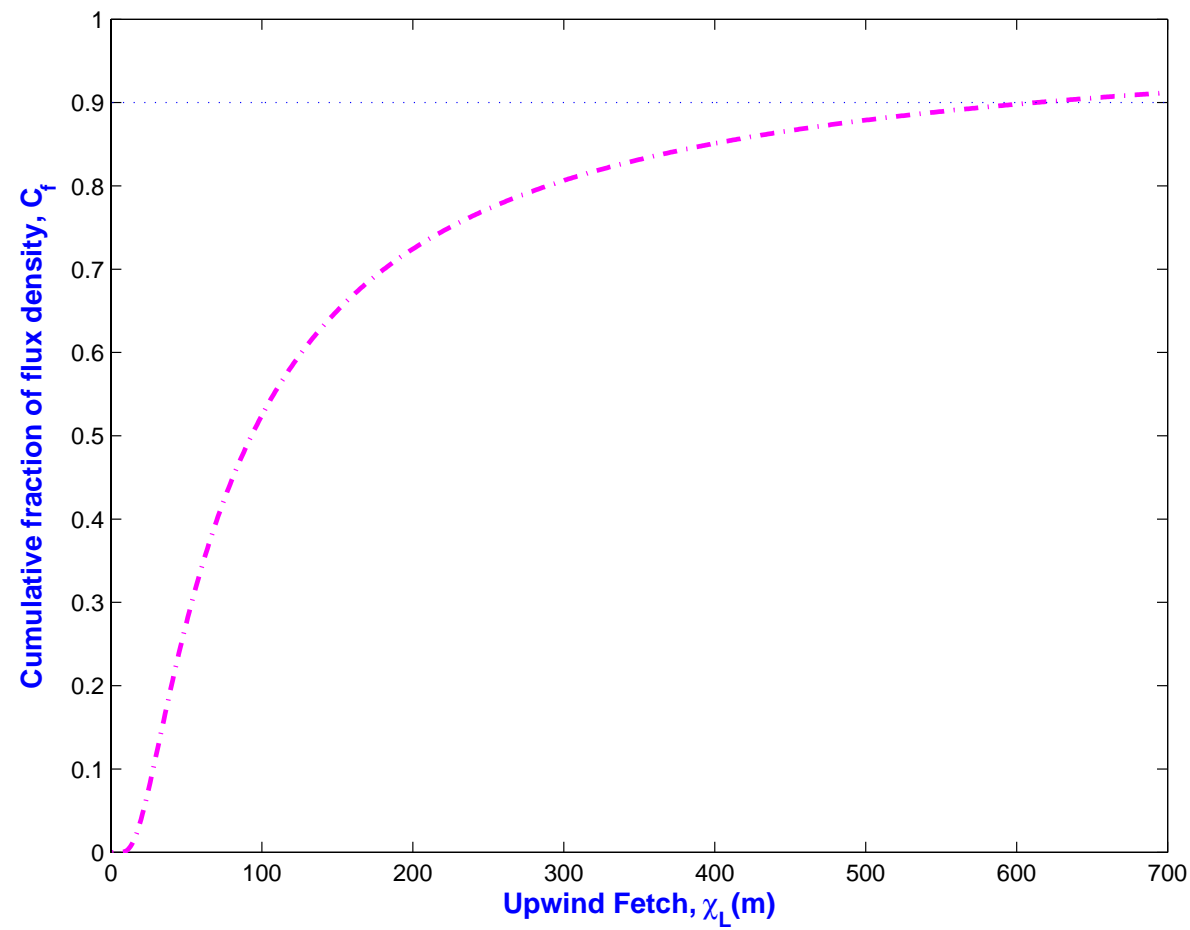

Flux measurements

in the near surface layer

Z. Gao et al.

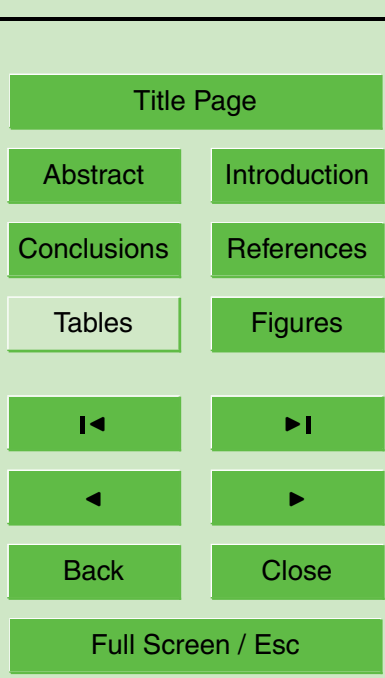

Fig. 2. Contribution of the cumulative flux, according to Eq. (7) for neutral stability of the experiment period.

Print Version

Interactive Discussion 
HESSD

2, 1067-1085, 2005
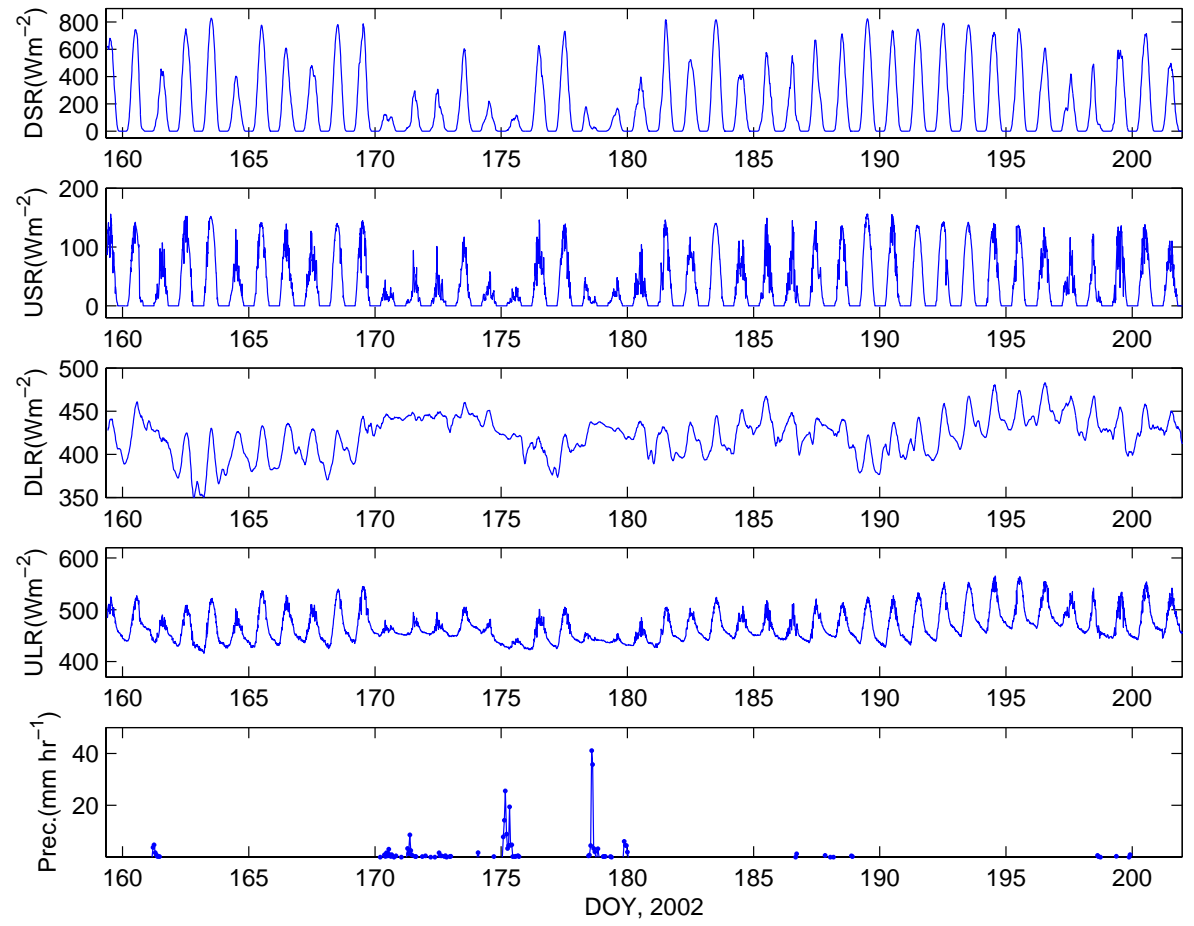

Flux measurements in the near surface layer

Z. Gao et al.

Title Page

\begin{tabular}{|c|c|}
\hline Abstract & Introduction \\
\hline Conclusions & References \\
\hline Tables & Figures \\
\hline 14 & $\rightarrow 1$ \\
\hline 4 & D \\
\hline Back & Close \\
\hline
\end{tabular}

Full Screen / Esc

Fig. 3. Variation of downward shortwave radiation $(D S R)$, upward shortwave radiation (USR), downward longwave radiation $(D L R)$ and upward longwave radiation $(U L R)$ fluxes and precipitation (Prec.) from 10 June to 20 July 2002 over a non-uniform crop surface.

Print Version

Interactive Discussion 
HESSD

2, 1067-1085, 2005

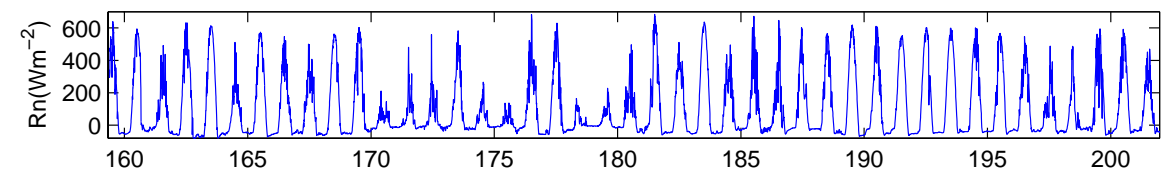

\section{Flux measurements in the near surface layer}
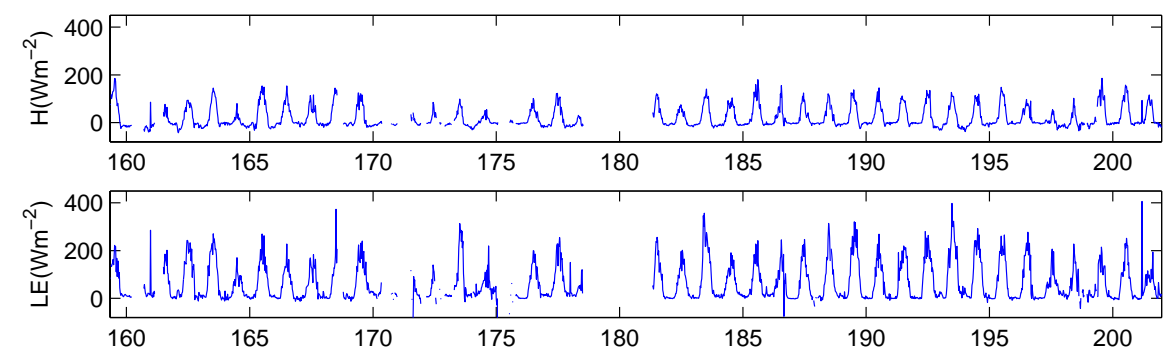

Title Page
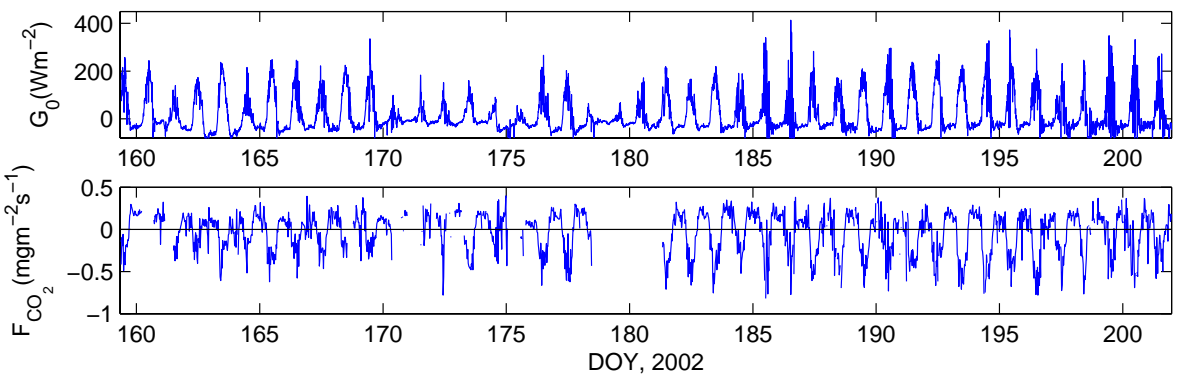

Z. Gao et al.

\begin{tabular}{|c|c|}
\hline Abstract & Introduction \\
\hline Conclusions & References \\
\hline Tables & Figures \\
\hline 14 & $\rightarrow 1$ \\
\hline 4 & $\triangleright$ \\
\hline Back & Close \\
\hline
\end{tabular}

Full Screen / Esc

Print Version

Interactive Discussion

EGU 
HESSD

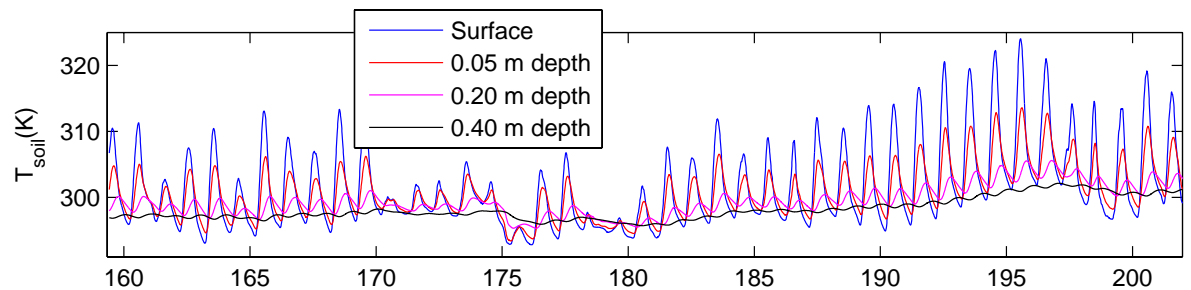

2, 1067-1085, 2005

\section{Flux measurements in the near surface layer \\ Z. Gao et al.}

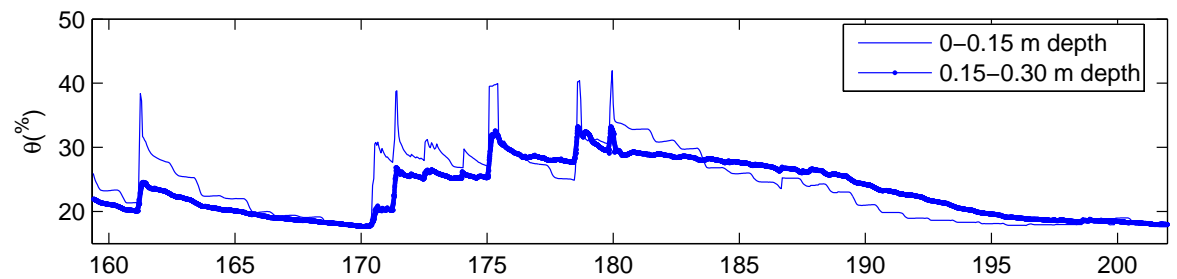

\section{Title Page}

\begin{tabular}{|c|c|}
\hline Abstract & Introduction \\
\hline Conclusions & References \\
\hline Tables & Figures \\
\hline 14 & $\rightarrow 1$ \\
\hline 4 & 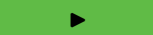 \\
\hline Back & Close \\
\hline
\end{tabular}

\section{Full Screen / Esc}

Print Version

Fig. 5. Variation of soil temperature at four depths, and soil volume water content from 10 June to 20 July 2002 over a non-uniform crop surface. 


\section{HESSD}

2, 1067-1085, 2005

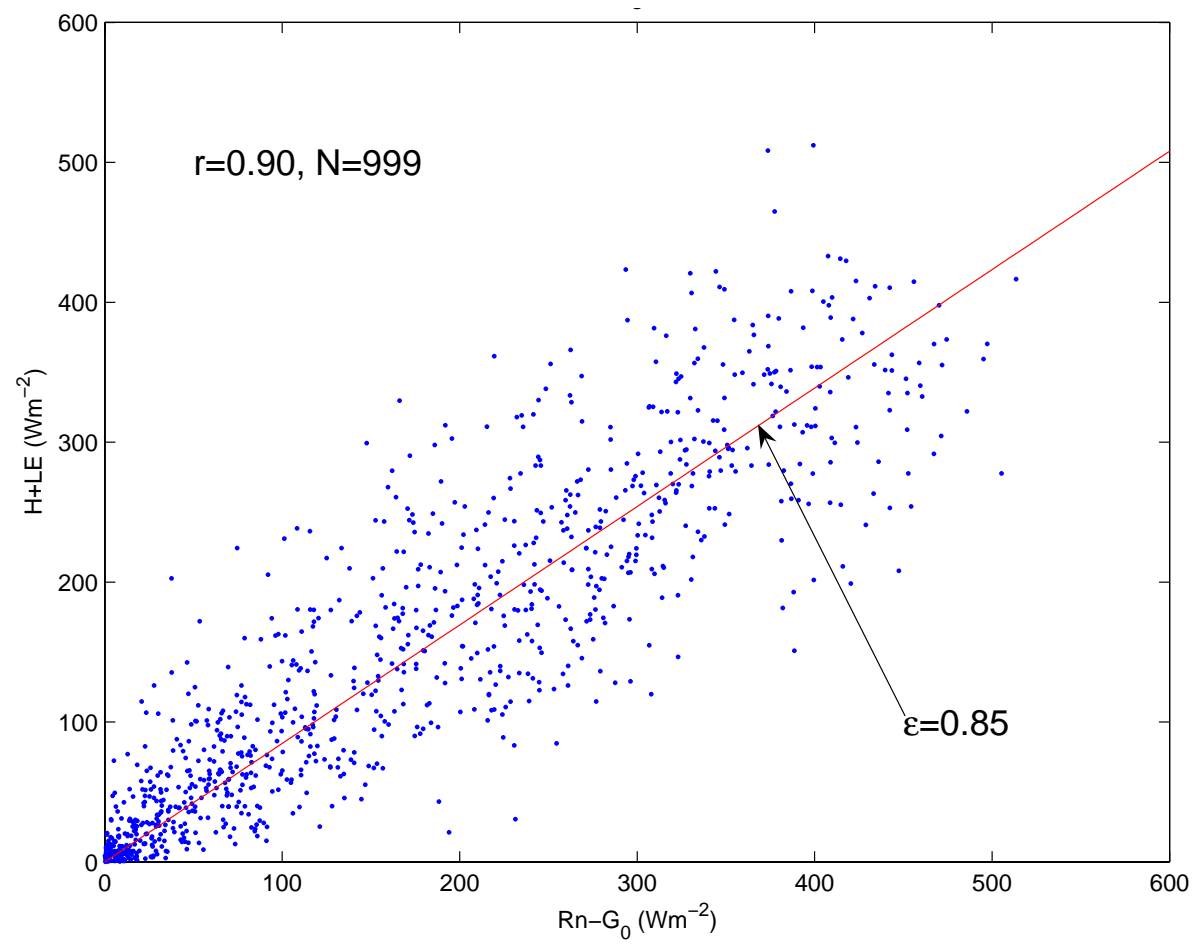

Flux measurements

in the near surface layer

Z. Gao et al.

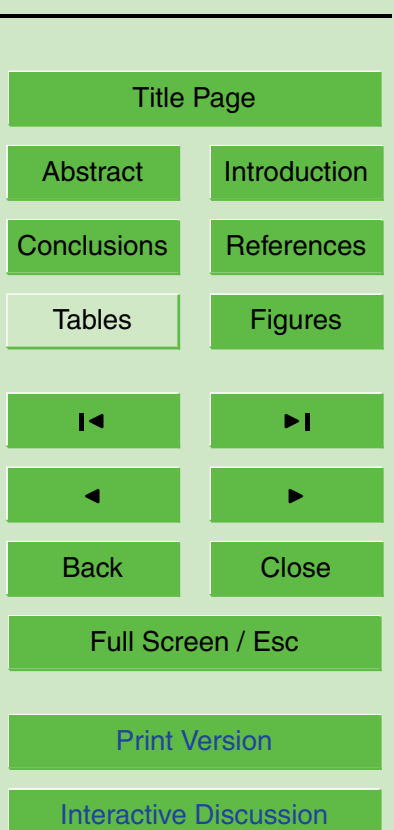

EGU 
HESSD

2, 1067-1085, 2005

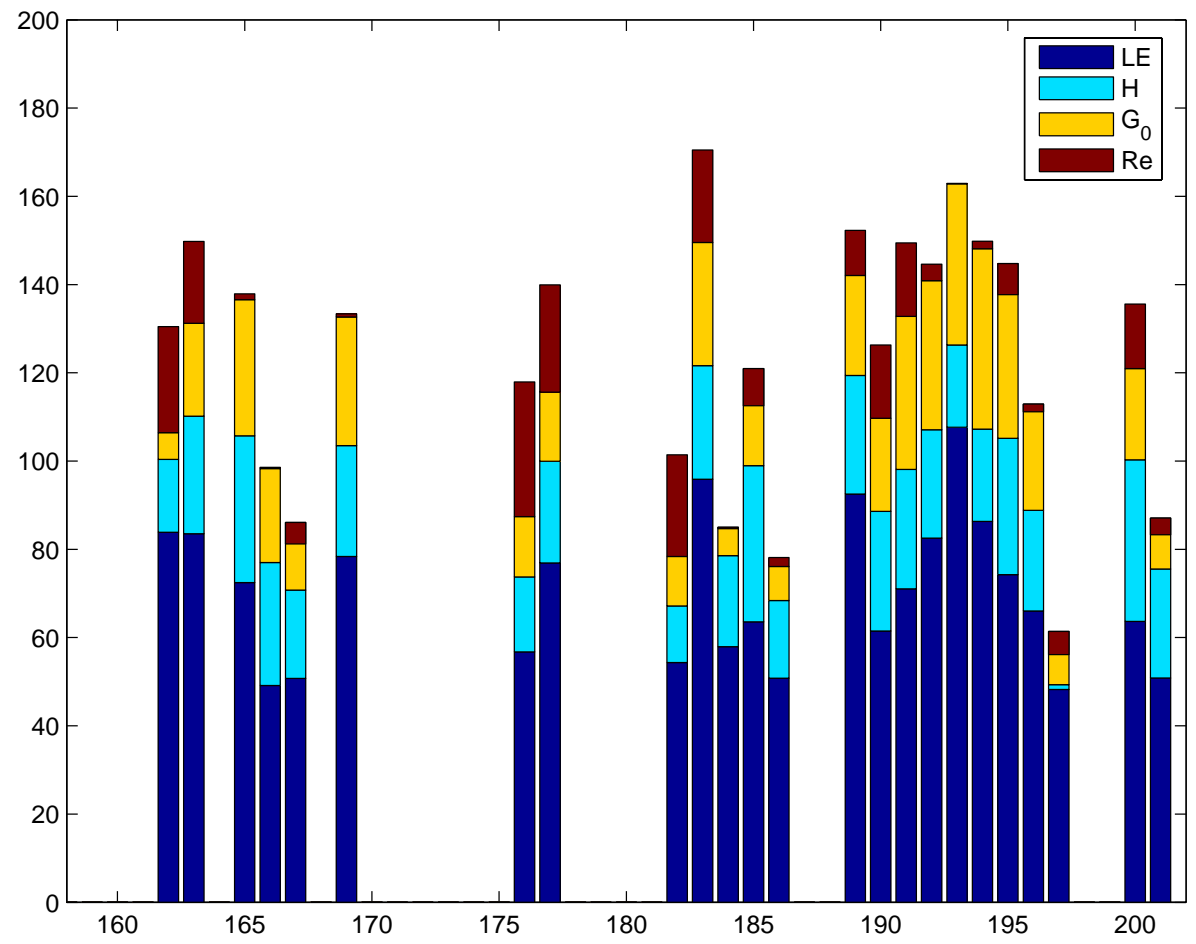

Flux measurements in the near surface layer

Z. Gao et al.

Title Page

Abstract

Conclusions

Tables

14

4

Back
Introduction

References

Figures

I

Close

Full Screen / Esc

Print Version

Interactive Discussion

Fig. 7. Bar plots of daily averaged latent heat flux $(L E)$, sensible heat flux $(H)$, soil heat flux $\left(G_{0}\right)$ and residual energy $(R e)$ for rain-free days during our experimental period. 